\title{
Financial stability analysis and forecasting insurance market of Russia
}

\author{
Mikhail K. Chernyakov ${ }^{1}$, Olesya V. Usacheva ${ }^{1,{ }^{* *}, \text { Natalia I. Aksenova }}{ }^{1}$, and Saidmuktori \\ Mukhtorzada $^{2}$ \\ ${ }^{1}$ Novosibirsk State Technical University, K.Marksa st., 20, 630073 Novosibirsk, Russia \\ ${ }^{2}$ Tajik State University of Commerce, Dehoti st., 1/2, 734055 Dushanbe, Tajikistan
}

\begin{abstract}
The article investigates the influence of various parameters and coefficients on financial stability, groups the factors according to their degree of influence and highlights the most significant for the insurance sector. We assumed the existence of a relationship between financial stability and indicators of debt burden, capital stock for meeting obligations, ratio of receivables and payables, expense ratio and loss ratio. The hypothesis was substantiated by analyzing investment investments of insurance companies in the real sector of the economy using the coefficient method and a prospective analysis of the paradoxical theory of regulation.
\end{abstract}

\section{Introduction}

A review of existing domestic and foreign approaches to the study of the financial stability of insurance organizations made it possible to establish the absence of a comprehensive methodology for assessing the financial stability of insurance organizations [1]. The issues of developing an effective mechanism for regulating the insurance industry based on a riskbased approach in accordance with Solvency II standards have received a fairly wide discussion in the scientific literature [2-5].

Thus, Mexican researchers assessed the impact of the second version of the international insurance capital standard (ICS) for international insurance groups adopted by the International Association of Insurance Supervision (IAIS) on the level of risks and the efficiency of foreign companies and compared them with their domestic counterparts. An increase in the risk of default by foreign insurers was established after the adoption of the law, and this negatively affected the level of financial stability of national insurers [3].

T.P. Kramarić, M. Miletić, and R.K. Blaževski have found that the insufficient size of the company and the amount of reinsurance coverage can jeopardize the financial stability of the insurer, and suggest that these elements be used by insurance supervisors as early warning indicators of the deterioration of the financial situation of insurers [6]. Russian scientist A.A. Turgaeva came to similar conclusions about the dependence of financial stability on the size of the insurance company [7].

\footnotetext{
${ }^{*}$ Corresponding author: Olesechka-nsk@yandex.ru
} 
Scientists from Kazakhstan, using a linear multivariate regression model, established the influence of financial leverage on the profitability of insurance companies [8]. G. Kalkabayeva, Z.Iskakova, and A. Rakhmetova highlighted the key factors affecting the investment opportunities of insurers and noted that investments in long-term projects lead to higher capital requirements of insurance companies and their solvency [9].

Domestic authors highlight the peculiarities of insurance and suggest a study of the financial potential of the insurer based on such indicators as: insurance rates and insurance reserves, the actuarial reserve adequacy for the fulfillment of insurance obligations, the ratio of the amount of net worth and assumed obligations [10].

Blazhevich O.G. proposes in the process of analyzing financial stability to investigate its characteristics such as: the adequacy of equity capital, the ratio of insurance premiums and insurance reserves, the provision of insurance reserves with own funds, the levels of debt ratio and insurance reserves, etc. [11].

EA. Khalyavka and O.A. Okorokov sees the leading directions of financial stability maintaining of an insurance organization in capitalization increasing and managing financial flows [12].

The conducted review of scientific research gives us reason to believe that the issues of financial stability of insurance companies are of undoubted interest among scientists from different countries, increasing in conditions of the financial crisis. Insurance companies are viewed not only from the standpoint of their internal financial stability, but also as a factor influencing the stability of state and global financial systems. In our study, we will focus on the financial stability of insurance companies in Russia and try to identify the key factors that affect it, taking into account the peculiarities inherent in the domestic insurance market. We believe that the results of the study will be of interest to both insurance companies and insurance supervisory authorities and foreign investors from the point of view of regulation of activities and investment attractiveness of the insurance sector.

\section{Materials and methods}

The theoretical and methodological basis of the study was the reviews of the insurers activities and their key indicators, conducted by the Federal State Statistics Service and the Central Bank of Russia in 2015-2020 (Table 1). For the convenience of the analysis, the selected parameters were designated as anonymous variables (X).

Table 1. Activities of insurers - legal entities registered in the Russia in 2015-2020, RUB bln

\begin{tabular}{|c|l|c|c|c|c|c|c|}
\hline X1 & Time period, year & 2015 & 2016 & 2017 & 2018 & 2019 & 2020 \\
\hline X2 & $\begin{array}{l}\text { Insurance premiums by insurance } \\
\text { types }\end{array}$ & 1028,64 & 1180,63 & 1278,84 & 1479,50 & 1480,19 & 1540,95 \\
\hline X3 & Investment income & 470,88 & 737,07 & 281,81 & 258,04 & 293,39 & 289,33 \\
\hline X4 & Insurance reserves & 973,55 & 1136,13 & 1448,46 & 1831,11 & 2514,28 & 2410,80 \\
\hline X5 & $\begin{array}{l}\text { Other income from insurance } \\
\text { activities }\end{array}$ & 34,62 & 45,62 & 37,23 & 26,64 & 28,82 & 25,42 \\
\hline X6 & Insurance proceeds & 511,75 & 505,79 & 509,72 & 522,47 & 609,61 & 659,27 \\
\hline X7 & Business expenses & 695,46 & 749,41 & 427,60 & 464,92 & 534,47 & 582,53 \\
\hline X8 & $\begin{array}{l}\text { Number of contracts concluded by } \\
\text { type of insurance, mln. units }\end{array}$ & 144,39 & 167,80 & 193,11 & 202,56 & 207,81 & 175,38 \\
\hline X9 & insurance income & 516,89 & 674,84 & 769,12 & 957,03 & 870,58 & 881,68 \\
\hline X10 & Equity capital & 178,49 & 216,36 & 204,79 & 200,06 & 218,96 & 219,80 \\
\hline X11 & Total equity & 395,49 & 461,99 & 605,41 & 677,27 & 810,34 & 876,30 \\
\hline X12 & Net profit (loss "-") & 91,22 & 81,93 & 84,01 & 164,92 & 207,35 & 201,04 \\
\hline X13 & $\begin{array}{l}\text { Accounts receivable (end of } \\
\text { period) }\end{array}$ & 357,70 & 346,00 & 282,20 & 290,50 & 318,20 & 332,97 \\
\hline X14 & Accounts payable (end of period) & 173,80 & 151,00 & 222,50 & 254,80 & 267,70 & 293,53 \\
\hline
\end{tabular}


In the course of the study, methods of analysis of investment investments of insurance companies in the real sector of the economy were used using the coefficient method [9], as well as prospective analysis of the paradoxical theory of regulation [13].

\section{Results and discussion}

Analysis of the investment potential of the Russian insurance market indicates a significant gap in the investment opportunities of domestic and foreign insurance companies, which is caused by their low level of capitalization and insufficient market development. The conclusions were confirmed when comparing specific indicators of the insurance market, for example, the total insurance premium, the level of penetration of insurance into the economy and the density of insurance in table 2 .

Table 2. Coefficients characterizing the financial stability of the insurance market

\begin{tabular}{|c|l|c|c|c|c|c|c|}
\hline X1 & Time period, year & 2015 & 2016 & 2017 & 2018 & 2019 & 2020 \\
\hline X15 & Ratio of AR to AP & 2,06 & 2,29 & 1,27 & 1,14 & 1,19 & 1,13 \\
\hline X16 & Pay-out rate by insurance types (rolling), \% & 49,7 & 42,8 & 39,9 & 35,3 & 41,2 & 42,8 \\
\hline X17 & Leverage & 2,46 & 2,46 & 2,39 & 2,70 & 3,10 & 2,75 \\
\hline X18 & Loss ratio, \% & 59,7 & 51,5 & 53,8 & 49,1 & 48,9 & 47,6 \\
\hline X19 & Expense ratio, \% & 38,1 & 38,1 & 36,8 & 35,8 & 39 & 42,6 \\
\hline X20 & Combined loss ratio, \% & 97,9 & 89,7 & 90,5 & 84,9 & 87,9 & 90,2 \\
\hline X21 & Debt ratio, \% & 5,6 & 5,1 & 2,1 & 2,5 & 4,7 & 2,8 \\
\hline X22 & $\begin{array}{l}\text { Capital stock for insurance contract } \\
\text { performance, } \%\end{array}$ & 40,6 & 40,7 & 41,8 & 37 & 32,2 & 36,3 \\
\hline X23 & Insurance fund financial strength ratio & 2,08 & 2,47 & 3,25 & 3,64 & 3,77 & 3,44 \\
\hline
\end{tabular}

The insurance fund financial strength ratio demonstrates stable positive dynamics (on average, about $11.44 \%$ per year, or $57.2 \%$ over 5 years). The coefficient was calculated using the formula:

$$
\mathrm{X} 23=(\mathrm{X} 2+\mathrm{X} 3+\mathrm{X} 4+\mathrm{X} 5) /(\mathrm{X} 6+\mathrm{X} 7)
$$

Leverage and expense ratio showed an unstable positive trend (about $2.5 \%$ per year), while the other ratios showed an unstable negative trend. A preliminary comparative analysis of tables 1 and 2 did not allow making an unambiguous conclusion about the relationship and interdependence of indicators of insurance activity and financial stability ratios, so it was decided to combine these tables and conduct a correlation analysis.

Correlation analysis showed the presence of a possible relationship between most indicators the activities of insurers and the coefficients of financial stability, however, for some, such a relationship is unlikely. Therefore, building a single-level model is not possible, and it was decided to build multi-level models. Taking into account the existing system of interconnections according to the paradoxical theory of regulation [13], we develop a regression model. The algorithm of the three-level model for determining the influence of the time period on the indicators of insurance activity is shown in Figure 1. 


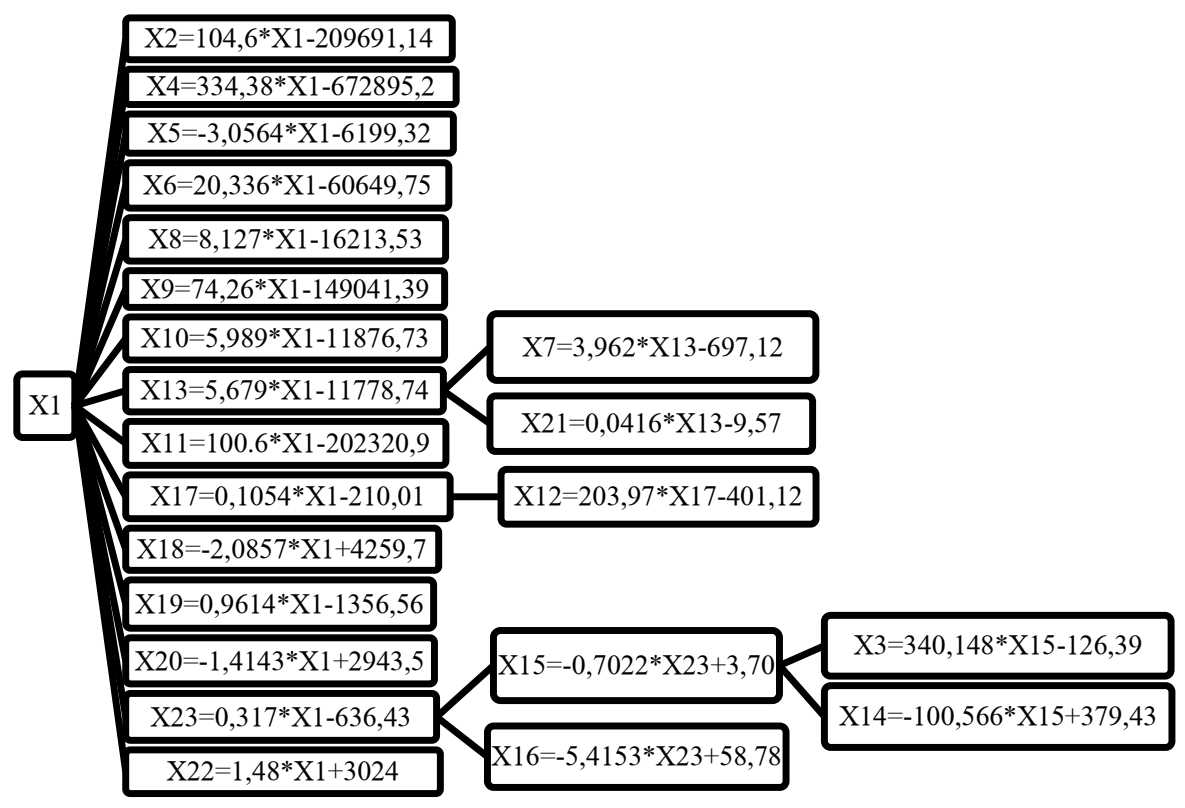

Fig. 1. Algorithm of the mathematical model of the insurance market of the Russian Federation, depending on the time period.

It should be noted that 15 parameters out of 22 with an error less than acceptable $(<15 \%)$ have a direct linear relationship with the time period (X1), 5parameters - an indirect relationship, through indicators of the first level (direct influence) and only two - secondary indirect relationship, through indicators of the second level direct influence).

The parameters of the third level of mutual influence include stagnating income from investments (X3) with an error of up to $50 \%$ and, to a lesser extent (an error of up to 22\%), an unstable growth of accounts payable (X14), although for the latter indicator the correlation coefficient was 0,94 .

The analysis of the algorithm shown in Figure 1 showed that the insurance fund financial strength ratio (X23) most fully characterizes the operation of the insurance market, and the least debt ratio (X21), which is also an indicator of the financial stability of insurers [14].

Based on the mathematical model of the Russian insurance market, depending on the time period (Fig. 1) made a forecast of the most probable state of indicators of insurance activity in the near future (Table 3).

Table 3. Forecast of the state of the insurance market of the Russian Federation for 2021-2023

\begin{tabular}{|c|c|c|c|c|c|}
\hline & $\begin{array}{c}\text { Actual } \\
\text { value }\end{array}$ & \multicolumn{3}{|c|}{ Projected value } & \multirow{2}{*}{$\begin{array}{c}\text { Statistical } \\
\text { discrepancy, }+/-\end{array}$} \\
\hline $\mathrm{X} 1$ & 2020 & 2021 & 2022 & 2023 & \\
\hline \multicolumn{7}{|c|}{ The first level of direct influence } \\
\hline $\mathrm{X} 2$ & 1592,95 & 1697,55 & 1802,14 & 1906,74 & $2,49 \%$ \\
\hline $\mathrm{X} 4$ & 2555,01 & 2889,39 & 3223,77 & 3558,15 & $7,38 \%$ \\
\hline $\mathrm{X} 5$ & 25,42 & 22,36 & 19,30 & 16,25 & $10,29 \%$ \\
\hline $\mathrm{X} 6$ & 628,94 & 659,28 & 689,61 & 719,95 & $4,63 \%$ \\
\hline $\mathrm{X} 8$ & 202,16 & 210,28 & 218,41 & 226,54 & $8,50 \%$ \\
\hline $\mathrm{X} 9$ & 964,01 & 1038,27 & 1112,53 & 1186,79 & $7,63 \%$ \\
\hline $\mathrm{X} 10$ & 221,38 & 227,37 & 233,36 & 239,35 & $3,95 \%$ \\
\hline $\mathrm{X} 11$ & 889,30 & 989,90 & 1090,50 & 1191,10 & $2,74 \%$ \\
\hline $\mathrm{X} 13$ & 307,06 & 301,38 & 295,71 & 290,03 & $7,48 \%$ \\
\hline $\mathrm{X} 17$ & 2,91 & 3,01 & 3,12 & 3,22 & $4,72 \%$
\end{tabular}


Table 3. Continued

\begin{tabular}{|c|c|c|c|c|c|}
\hline $\mathrm{X} 18$ & 46,55 & 44,47 & 42,38 & 40,30 & $3,17 \%$ \\
\hline $\mathrm{X} 19$ & 40,13 & 40,82 & 41,51 & 42,20 & $4,04 \%$ \\
\hline $\mathrm{X} 20$ & 86,65 & 85,23 & 83,82 & 82,40 & $2,85 \%$ \\
\hline $\mathrm{X} 22$ & 34,40 & 32,92 & 31,44 & 29,96 & $4,77 \%$ \\
\hline $\mathrm{X} 23$ & 3,90 & 4,22 & 4,53 & 4,85 & $9,36 \%$ \\
\hline \multicolumn{6}{|c|}{ The second level of direct influence } \\
\hline $\mathrm{X7}$ & 492,01 & 496,98 & 474,48 & 451,98 & $3,84 \%$ \\
\hline $\mathrm{X} 12$ & 210,29 & 225,08 & 251,47 & 277,87 & $9,56 \%$ \\
\hline $\mathrm{X} 15$ & 0,94 & 0,73 & 0,51 & 0,29 & $9,96 \%$ \\
\hline $\mathrm{X} 16$ & 38,81 & 35,94 & 34,23 & 32,51 & $6,23 \%$ \\
\hline $\mathrm{X} 21$ & 2,74 & 2,97 & 2,74 & 2,50 & $6,10 \%$ \\
\hline \multicolumn{6}{|c|}{ The third level of secondary indirect influence } \\
\hline $\mathrm{X} 3$ & 226,81 & 162,17 & 97,52 & 32,88 & $8,01 \%$ \\
\hline $\mathrm{X} 14$ & 297,30 & 310,40 & 334,47 & 358,54 & $3,69 \%$ \\
\hline
\end{tabular}

The forecast results indicate that among the factors that have a direct impact on the financial stability of insurance companies, five will continue to decline. Noteworthy is the trend of capital growth in insurance companies, the growth of leverage and, in fact, the key indicator - the coefficient of financial stability of the insurance fund. The reliability of the forecast is confirmed by the calculated risk of deviation, not exceeding $10 \%$. Among the factors of indirect influence, the decline in investment income, the ratio of accounts receivable and payable and the pay-out rate by insurance types will continue, which will negatively affect the state of insurance companies. However, there are also positive trends, namely: a decrease in the business expenses and the debt ratio and an increase in the net profit of insurance companies. Thus, we believe that the financial strength of insurance companies will gradually grow.

\section{Conclusion}

The study made it possible to differentiate the factors affecting the stability of the insurance companies' activities, identifying three groups of them: direct influence, indirect influence and secondary indirect influence. The interrelation of the coefficient of financial stability of the insurance fund with the parameters and coefficients of insurance activity was determined by the method of correlation-regression analysis. Based on the analysis, the forecast values of the factors and the most effective indicator - the financial stability of the insurance fund were calculated. The study contributes to the development of theoretical approaches to assessing the financial stability of insurance companies based on the paradoxical theory of regulation. The practical value of the study lies in the possibility of using the proposed approach to assess and predict the financial stability of insurers, taking into account various parameters.

\section{Acknowledgement}

This work was supported by the Novosibirsk State Technical University (project C21-11).

\section{References}

1. A.V. Larionov, Journal of Applied Economic Research, 19, 208 (2020)

2. J. Nikitchenko, L.Vasyukova, Bulletin of the Far Eastern Federal University. Economics and Management, 89, 123 (2019) 
3. N. Gavira-Durón, D. Mayorga-Serna, A. Bagatella-Osorio, The Geneva Papers on Risk and Insurance - Issues and Practice (2020)

4. R. Düll, F. König, J. Ohls, Journal of Financial Stability, 31, 93 (2017)

5. S. García, J.M. Pavía, E.J. Veres Ferrer, J. Lledó, Estudios de Economía Aplicada, 35, 367 (2019)

6. T. Pavić Kramarić, M. Miletić, R. Kožul Blaževski, Business Systems Research Journal, 10, 163 (2019)

7. A. A. Turgaeva, Finance and Credit, 23, 89 (2017)

8. A. Kulustayeva, A. Jondelbayeva, A. Nurmagambetova, A. Dossayeva, A. Bikteubayeva, Entrepreneurship and Sustainability Issues, 7, 2394 (2020)

9. G. Kalkabayeva, Z. Iskakova, A. Rakhmetova, Bulletin of the national academy of sciences of the republic of Kazakhstan, 4, 339 (2020)

10. N. V. Kirillova, Property relations in the Russian Federation, 9, 85 (2019)

11. O. G. Blazhevich, Scientific Bulletin: Finance, Banking, Investment, 2, 68 (2020)

12. E. A. Khalyavka, O.A. Okorokova, International journal of humanities and natural sciences, 11-3, 198 (2020)

13. M. M. Chernyakova, The Paradoxical theory of Regulation (2019)

14. I. Moreno, P. Parrado-Martínez, A. Trujillo-Ponce, Accounting \& Finance, 60, 2965 (2020) 